\title{
Networks in The Implementation of Illegal Gold Mining Countermeasure Policy in Kuantan Singingi Regency
}

\author{
Trio Saputra ${ }^{*}$, Arief Darmawan ${ }^{2}$, and Rachmawati Novaria ${ }^{2}$ \\ ${ }^{1}$ Fakultas IImu Administrasi, Universitas Lancang Kuning, Jl. H.R Soebarantas KM.08 Rumbai \\ Kecamatan Rumbai, Kota Pekanbaru, Indonesia \\ ${ }^{2}$ Fakultas IImu Sosial dan IImu Politik, Universitas 17 Agustus 1945 Surabaya, Jl. Selomowaru No.45 \\ Kota Surabaya, Indonesia.
}

How to cite: Saputra, Trio., Darmawan, Arief., \& Novaria, Rachmawati. (2021). Networks in the Implementation of Illegal Gold Mining Countermeasure Policy in Kuantan Singingi Regency. Jurnal Borneo Administrator, 17(3), 335-350. https://doi.org/10.24258/jba.v17i3.938

\section{Article History}

Received: 03 August 2021

Accepted: 16 November 2021

\section{Keywords:}

Illegal gold mining, Policy Implementation, Stakeholders

\begin{abstract}
This study aims to determine the implementation of the Illegal Gold Mining (IGM) Countermeasure policy in the Kuantan Singingi Regency. This study uses a multisectoral multi-organizational network model consisting of a Contextual Assessment approach to understanding the environmental context and identifying stakeholders in policy implementation and joint visioning. This study critically examines the IGM in the regency in qualitative perspective from various related articles. A systematic literature review was used to analyze national and international journal articles from nine managed databases based on these concerns. From the literature review, 22 relevant research-based articles in the last 15 years from 2007 to 2020 were selected from Google Scholar, Taylor, Francis Outline, Springer Link, Emerald Insight, Science Direct, Sage Journal Online, and Oxford Cambridge. Three stages were carried out: preparation, screening and validation, and content review. The findings include 1) research showing that stakeholders involved from both government and community groups do not play an active and synergistic role in controlling IGM. 2) the implementation model of the IGM countermeasure, the government, the private sector, and the community must support each other in controlling and supervising IGM.
\end{abstract}

\section{A. INTRODUCTION}

Riau Province is well known for its resources of minerals and mines. Some potential resources are oil, coal, and gold. Mining areas are easy to find in this province. The Government Regulation of the Republic of Indonesia Number 23 of 2010 on Implementation of Minerals and Coal Mining Business Activity states that mineral commodities are minerals that can be used to fulfil the needs of people. Some of them are Bauxite, Titan Gold, Copper, Iron, and other types of metals. Many mining activities create environment problem because most of them are illegal in accordance with the Ministry Regulation of Energy and Mineral Resources Number 26 of 2018 on Implementation of Good Mining Practices and Supervision of Mineral and Coal Mining.

Kuantan Singingi Regency, in Riau Province, is one of the pioneers that put concern on environment issue due to increasing illegal mining activities. The activities tend to decrease

\footnotetext{
* Corresponding Author

Email : trio.unilak@gmail.com
} 
the water quality in the area, and therefore it needs strict scrutiny. Kuantan Singingi Regency has 15 Sub-Districts (Kecamatan), 11 Wards (Kelurahan), and 218 Villages. Kuantan Singingi Regency has two major rivers that cross its territory, i.e., Kuantan River and Singingi River. The rivers have major roles in the livelihood of the residents, especially for transportation, aquaculture, agriculture, and hydroelectric power supply.

Based on the data from the Department of Mining, Energy, and Mineral Resources of Kuantan Singingi Regency, the mining area within the regency is approximately $12,413.37$ hectares which contain alluvial gold. Due to many illegal gold minings (Pertambangan Emas Tanpa Izin / PETI), the local government proposes to the central government to change the gold mining areas into Small-Scale Mining Areas (Wilayah Pertambangan Rakyat / WPR) and managed by local communities. Based on the Ministry Decree of Energy and Mineral Resources Number 1095/K/30/MEM/2014 on Enactment of Small-Scale Mining Area in Sumatra Island, thus, 24 Small-Scale Mining Areas were established in Kuantan Singingi Regency.

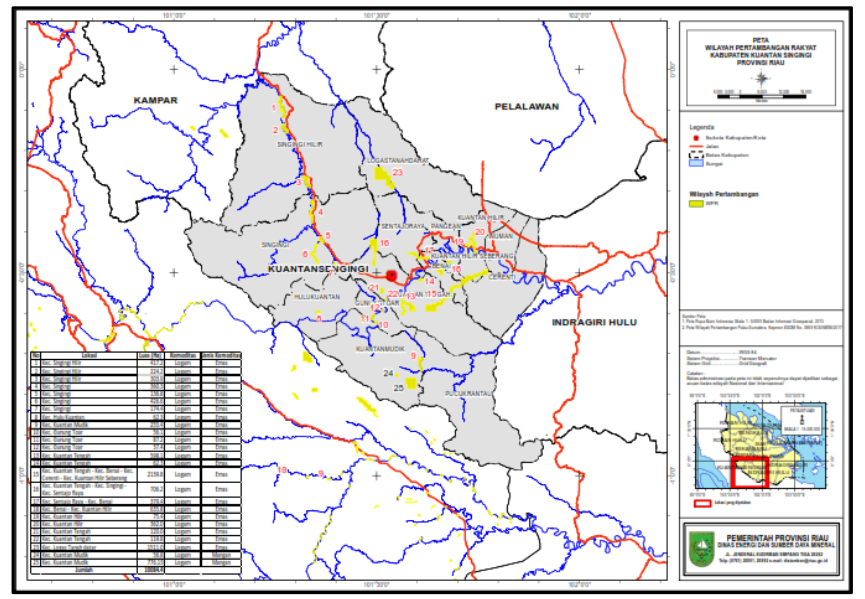

Figure 1. Small-Scale Mining Area Map

However, the Small-Scale Mining Area policy does not solve the main problem, i.e. the illegal mining activities, and they are still ongoing. The policy does not legalize the mining activities, because it will against the law. The policy intervention does not also decrease the number of illegal minings. The next problem is the absence of operational regulations and policies which tackle the existence of illegal minings, including the implementation of SmallScale Mining Areas policy. Beside environmental problem, vertical and horizontal conflicts are often occurred in the illegal mining areas. Illegal gold mining (IGM) activity is known as dompeng referring to local term in this regency.

Mining licence is regulated in the Law Number 4 of 2009 and amended by the Law Number 3 of 2020 on Mineral and Coal Mining. IGM is a mining activity which is conducted without any licency from an authorized agency or government as the proprietor of the mineral commodities. Article 35 Section (2) Point c of the Law Number 3 of 2020, mentions that required permits for the miners are classified in to nine types. They include Mining Permit, Special Mining Permit, Special Mining Permit as Continuation of Contract/Agreement Operations, Small-Scale Mining Permit, Rock Mining Permit, Assignment Permit, Transportation and Sales Permit, Mining Service Permit, and Sale Permit.

There are regulations regarding permits required for the gold miners and meting out punishments to those who exercise IGM. Article 151 to 164 of the Mineral and Coal Mining Law states that whoever carries out illegal mining shall be punished to a maximum imprisonment of 5 (five) years and a maximum fine of IDR 100,000,000,000.00 (one hundred 
billion rupiahs). However, regarding IGM in Kuantan Singingi Regency, there is still no local Law (Peraturan Daerah-Perda) that regulates the mining issue.

An excessive amount of IGM activities performed by the communities have negatively created negative results both on the environment and the citizens. The study found out the direct impacts including pollution of river water, land subsidence around the river, dwindling water ecosystems resulting in a reduced amount of fisherman's catch, and soil erosion due to excessive excavation.

According to Law Number 23 of 2014 on Regional Government, IGM case is categorized as utilizing energy and mineral resources which is the central government's authority. However, so far there is not any rule or effort from the central government to tackle this issue. Thus, the authority to regulate the IGM is still on the local government.

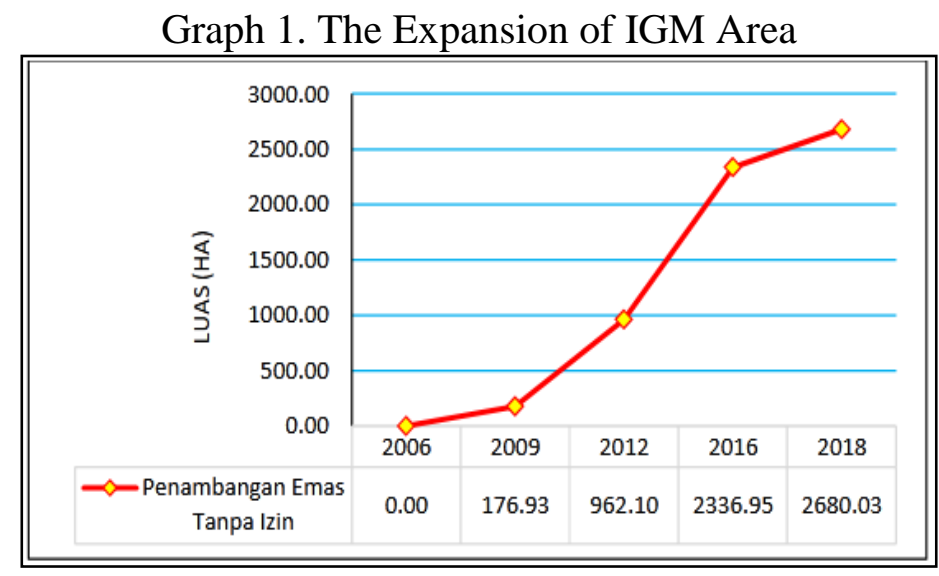

Graph 1 shows the area of IGM had expanded from 2006 to 2018, indicating a deluge of gold mining activities. The scope of IGM had expanded from 176.93 hectares in 2009 to $2,680.03$ hectares in 2018. The local government is responsible for preserving the environment as the environmental damage due to gold mining activities have been expanded and negatively resulted a problem among the community.

The efforts conducted by the local government have not yielded optimum results. It is seen in the recurrence of IGM, though such activities have been brought under control by the security forces. Counselling, socialization, and raid operations have been conducted. Mitigation of illegal gold minig impacts is conducted through Decree of Regent Number 13 of 2013 on the Formation of IGM Control Team in Kuantan Singingi Regency. Tis effort involves many stakeholders such as the local and village governments, youth organizations, the police, the army, and Datuak/Ninik Mamak. The policy implementation often employs various policy approaches, one is called a policy network. The policy network is directed to build cooperation among the stakeholders in implementing the countermeasures for IGM. The network approach in public policy has developed rapidly with the growth of cluster and quango organizations due to the interaction between the Government, Non-Government, and Community.

Multi-stakeholder cooperation networks are expected to create a positive impact, including increasing the commitment of local government and stakeholders, increasing stakeholders' sense of ownership and responsibility in utilizing and maintaining development results, ensuring sustainability, and rising public trust.

The urgency of this research is to achieve sustainable policy in environmental development through the implementation of IGM countermeasure policy in Kuantan Singingi Regency by forming multi-organizational and multi-sector cooperation, e.g. among the government, local tribes, and non-governmental organizations, by observing the socio-political conditions. This study has the following research questions: 
RQ.1:How is the IGM countermeasure policy implemented in Kuantan Singingi Regency?

RQ.2:How is the implementation model of IGM countermeasure policy in Kuantan Singingi Regency?

\section{B. LITERATURE REVIEW}

Some previous researches discussed the IGM from various perspectives, such as economic, social, prevention, and law enforcement (Haridison, 2016; Buli, 2018; Muhammad, 2019; Abdullah, 2016; Santoso, 2018; Fahmi, 2017; Owusu, E. E., \& Dwomoh, 2012; Sujatmiko, 2012; Arlianti, 2017). However, they have not revealed the variables in detail, including the connections between various variables in public policy implementation in the IGM countermeasure process that may significantly reduce illegal mining in Indonesia. Thus, this study attempts to fulfil gap.

The network model comprehends that policy implementation is a process of complex interaction among numerous independent stakeholders inside the network. Interactions in the network will determine how the implementation should be executed, how the issues need to be prioritized, and how the discretions are expected to be important elements. One of these models was developed by Kickert (1997).

The policy network is depicted in several categories. First, it is described as actors. Second, its linkages between the actors. Third, the boundary (Carlsson, 2000). Meanwhile, Marsh and Rhodes (1992) use the term network to delineate several parties involved in providing services. The organizations weave these networks by exchanging resources (e.g., money, information, expertise) to achieve their aims, maximize their influence towards the result, and avoid dependency with other parties in executing their roles.

Sabatier and Smith (1993) investigate a policy network and name it Advocacy Coalition, which refers to a group of policymakers in a policy subsystem. The stakeholders in the advocacy coalition consist of actors from various private institutions and governments in all levels of governmental organization based on trust in goal achievements (Howlett, 1995). This trust system underlies the connections between stakeholders consisting of 3 levels of trust, i.e.: (1) Common belief or deep/normative core, trust and common perception towards the policy goal based on the common knowledge about the public issues interest the stakeholders. This trust is often related to basic human nature, both as an individual and as a collective group. Trust that originates from basic human nature is hard to modify. (2) Core of belief system, a trust system based on the common view of human basic nature and several conditions desired by humans. The coalition based on this trust system is very stable and hard to change. (3) External factors include money, expertise, supporters, legal authority, public opinion, technology, inflation level, and cultural values. The trust system formed through external factors is relatively easy to change (Suwitri, 2008).

From these various elucidations, it can be concluded that the network model in the policy implementation requires methodology or a new approach in performing it, as, without such methods or approaches, the success of a program is hard to achieve. The coordination dimension is a novelty in this research since the Concept of Multi-Organizational. Multi-Sector Structures for Policy Implementation theory, according to Schroeder (2001), only touches the structure without scrutinizing the coordination, while coordination is also influential in the interaction process of resolving public issues and achieving the goal of the organizational network. Therefore, this study attempts to analyze the implementation of IGM countermeasure policy. This is mainly from the policy network perspective to develop a model to achieve an effective illegal mining countermeasure in Kuantan Singingi Regency. 


\section{METHOD}

This research adopted Xiao (2019). As the systematic qualitative review guide, the framework used thematic synthesis review (Thomas, J., \& Harden, 2008). The procedure has three stages: preparation, filtering and validation, content review, and synthesis and reporting. Each stage has several steps, as depicted in Figure 2. The literature was searched in the first content review stage based on abstract and publication date.

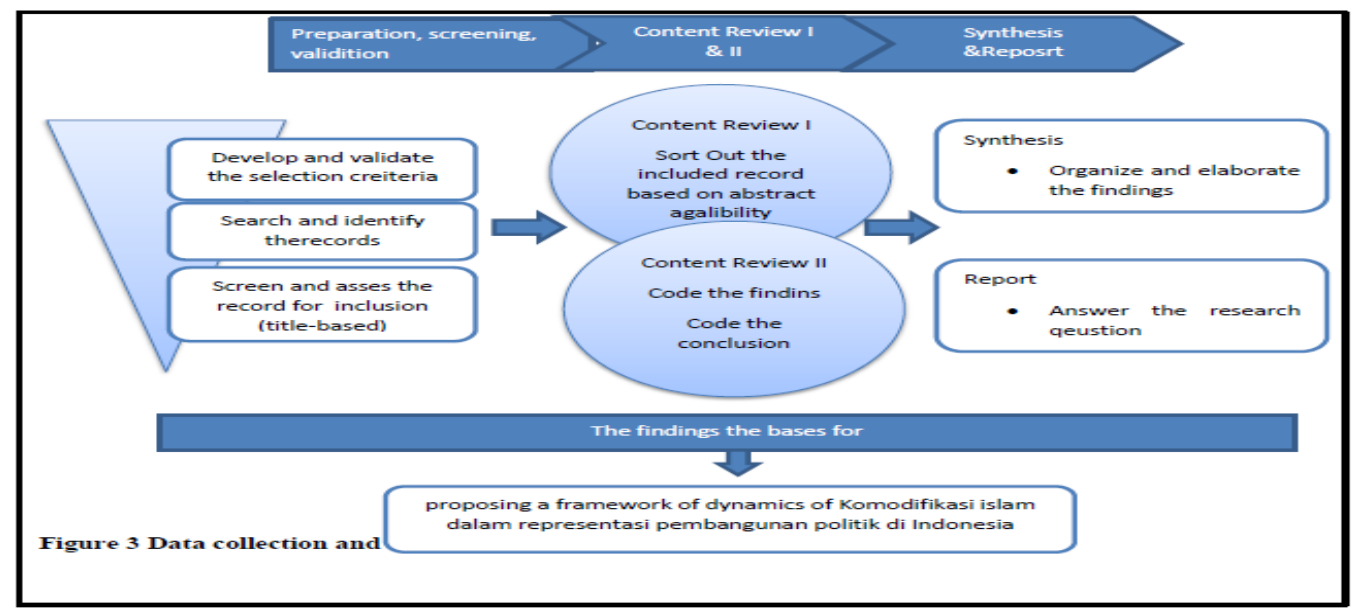

Figure 2 .Thematic Synthesis Review Steps

\section{Planning}

The authors identified or formulated problems, objective reviews, and protocol reviews in this stage. These reviews contained the research question: RQ.1: How is IGM countermeasure policy implemented in Kuantan Singingi Regency? RQ.2: How is the implementation model of IGM countermeasure policy in Kuantan Singingi Regency?

\section{Search Strategy}

For review, several general databases were used: Google Scholar, Taylor, Francis Outline, Springer Link, Emerald Insight, Science Direct, Sage Journal Online, and Oxford Cambridge. The searches were performed using keywords related to this research topic (See table 2). The searches were limited to the publication year 2007-2020. These groups were collected and analyzed systematically through the title-abstract-keyword procedure from the articles indexed in the databases. Finally, this systematic review also included relevant potential research in the article reference list.

Table 1. Selected keywords in different groups

\begin{tabular}{ll}
\hline $\begin{array}{l}\text { Group 1 - Keywords related to the } \\
\text { implementation of illegal mining policy }\end{array}$ & $\begin{array}{l}\text { Policy implementation, illegal mining, policy network, } \\
\text { building implementation networks }\end{array}$ \\
\hline Group 2 - Publication year & $\begin{array}{l}\text { The year 2007-2020 } \\
\text { Group 3 - Types of documents }\end{array}$ \\
Jroup 4 - Language & English and Indonesia \\
The last search from the formulation & Group 1-Group 4 \\
\hline
\end{tabular}

\section{Inclusion and Exclusion Criteria}

Inclusion and exclusion criteria were used and developed for this research. The inclusion criteria used in this research included: year period, articles' language, and theme related to this research topic (see table 2). 
Table 2. List of Inclusion and Exclusion Criteria

\begin{tabular}{lll}
\hline \multicolumn{1}{c}{ Criteria } & \multicolumn{1}{c}{ Include } & \multicolumn{1}{c}{ Exclude } \\
\hline Period & $2007-2020$ & Any study outside these years \\
Language & English and Indonesian & Non-English and Indonesian \\
Study focus & Implementation of IGM & Any study outside this focus \\
& countermeasure policy & \\
\hline
\end{tabular}

From the criteria above, after screening 118 articles, the result is as follows:

1. From 181 articles obtained, 90 were selected based on the publication year.

2. From 90 articles, 30 articles were selected based on abstract and title.

3. From 30 articles, 22 articles were selected based on relevance to the theme/topic.

Content Review II was started by reading the articles comprehensively and focused more on findings, discussions, and conclusions for the synthesis and reporting stage. First, the opencontent technique was employed to decipher the meaning of each word from the sentences. Then, the retrieved codes were classified into several categories, which directly answered the research questions. In the synthesis and reporting stage, the coherence of information projected in the codes within each category was re-examined. The re-examination result was used in compiling the presentation for findings. Thus the three main discussion themes in this research could be elaborated clearly.

\section{RESULT AND DISCUSSION}

The literature review managed to retrieve 22 articles from 2007-2020 which were relevant to the topic discussed in this literature. This part deciphered information about the network implementing an IGM countermeasure policy. The research questions in the introduction were discussed accordingly. The literature review was represented in two discussion themes: the implementation of IGM policy $(n=8)$ and the policy implementation model in IGM countermeasure $(n=14)$, as depicted in the Graph 2. The overview of the content of the articles is presented in the following categories: writer, year, keywords, search code, and relevance to this research theme (see table 4).

Graph 2. The Main Themes of The Findings

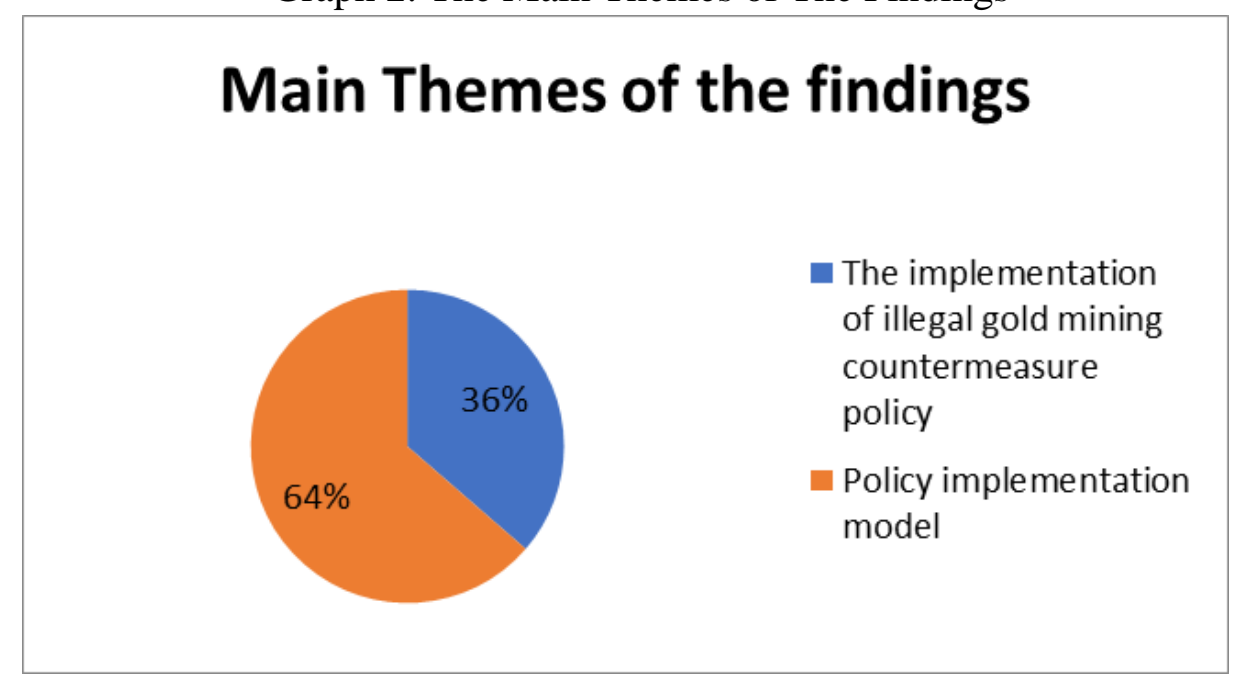


Table 3. Sample of Coding and Categorization Results

\begin{tabular}{|c|c|c|c|}
\hline $\begin{array}{c}\text { Author \& Publication } \\
\text { Year }\end{array}$ & Key Findings & Code & Theme \\
\hline $\begin{array}{l}\text { (Biosca, O., \& Galaso, } \\
\text { 2020) }\end{array}$ & $\begin{array}{l}\text { The organizational network involved in } \\
\text { implementing public policy needs reliable } \\
\text { interaction, cooperation, and a high level of } \\
\text { collaboration to ensure its effectiveness. The } \\
\text { intensity of partnership can also determine } \\
\text { the organization's involvement within the } \\
\text { network. The nature of funding } \\
\text { (public/private) and the authority of the } \\
\text { organization's activities are identified to } \\
\text { determine the influence and interest of } \\
\text { social policy network }\end{array}$ & $\begin{array}{l}\text { Policy } \\
\text { implementation }\end{array}$ & $\begin{array}{l}\text { The } \\
\text { implementation } \\
\text { of an IGM } \\
\text { countermeasure } \\
\text { policy }\end{array}$ \\
\hline
\end{tabular}

The literature review was represented in two discussion themes: the implementation of IGM policy $(n=8)$, the policy implementation model in IGM countermeasure $(n=14)$

\section{RQ.1: How is IGM countermeasure policy implemented in Kuantan Singingi Regency?}

Based on the literature on policy implementation, three role conflicts have been identified and considered essential when implementing public policy, i.e., policy-professional role conflict, policy-client role conflict, and organizational-professional role conflict (Tummers, L., Vermeeren, B., Steijn, B., \& Bekkers, 2012). A policy conflict starts from the implementation process where different perspectives regarding the purpose and means to achieve it occurs (Veronesi, G., \& Keasey, 2015). Understanding the first and most crucial challenge in public policy implementation is the leadership role. Leaders are crucial because they focus on three fields: (1) pioneering participative development to reform public sectors from a vision; (2) motivating and producing the best staff; and (3) encouraging more direct involvement from stakeholders in the implementation of reformation and thus stimulating responsiveness and public accountability in providing service for the needs and demands of the public and clients (Rahman, M. H., Naz, R., \& Nand, 2013). It is crucial to understand policy implementation's roles, conflicts, and challenges. Observing the relatively big common challenges for the role towards the desire to implement policy, it is necessary and crucial to understanding the conflicts and role challenges while studying the policy implementation (Tummers, L., Vermeeren, B., Steijn, B., \& Bekkers, 2012).

It is imperative to view the mining policy in Indonesia comprehensively since it is usually related to non-mining sectors, e.g., agriculture, fishery, environment, and forestry. According to Sunardi (2017), the law regarding the development of mineral and oil and gas resources in Indonesia can be divided into three groups, i.e., during the colonial period, during a transition period, and the period after Law Number 11 of 1967.

Furthermore, Wahiyuddin (2020) elucidates that there were laws referred to as the source of law in Indonesia's mining history. First, Indische Mijnwet (IMW) was enacted in 1899 with Staatblad Number 214 of 1899 which only regulated minerals and mining company classification. Second, Law Number 5 of 1960 on Basic Agrarian Principles regulates land rights for development in the mining sector. Third, Law Number 11 of 1967 on Basic Mining Principles was enacted on December 2nd, 1967, regulating general principles of mining, classification/control of minerals, state levies, mining business, mining authorization, and mining supervision. Fourth, Law Number 22 of 2001 on Oil and Gas, regulating oil and gas business activities. Fifth, Amendment of Law Number 4 of 2009 into Law Number 3 of 2020 on Mineral and Coal Mining, regulating mineral and coal mining business permits in more detail. 
These government regulations regulated part of the authorities to grant permits and supervision in the mining sector in general to the central government, which was originally the authority of local governments. When Regulation of Government Number 75 of 2001 was issued, many regencies and cities did not yet have mining and energy departments. However, all provincial governments already had mining departments at the time. The mining and energy ministry only had 15 regional offices. Some provinces which did not have regional offices had their mining-related activities handled by a liaison office or mining area office (Darmono, Djoko, 2009).

On the other hand, the organizations within the local governments were not ready since the organizational structure for mining was not arranged yet at the regency/city level. Thus the implementation of mining-related services was still not adequate. It was deemed necessary to create local organizational apparatus in providing public services and optimizing service performance in the mining sector.

The IGM Countermeasure policy in Kuantan Singingi Regency was enacted through Decree of Regent Number 13 of 2013 on the Formation of IGM Control Team in Kuantan Singingi Regency after the Law Number 23 of 2014 on Local Government was issued. At the same time, Regulation of Government Number 18 of 2016 on Regional Organization Unit allowing regions to abolish the Energy and Mineral Resources Department at the regency level and to exclusively give all forms of tasks and authorities to the provincial level, which was executed by Energy and Mineral Resources Department of Riau Province until 2017.

Based on the regulation, there is no longer any agency in charge of mining at the Regency level. Thus, the regency did not have the authority to supervise the mining sector. However, the abolition of the mining department at the regency level did not abolish its organizational structure entirely. It still existed in the natural resources division of the regional secretariat, including in Kuantan Singingi Regency.

Small-Scale Mining Permit was yet implemented as the government of Riau Province had not ratified a small-scale mining permit in Kuantan Singingi. Therefore, as small-scale gold miners, the residents were still unable to legalize their mining activities. Hence, the role of the government was very imperative in policy-making. This is also supported by Ferry (2013) in his research. Good governance at local and regional levels can promote growth and robust economic development.

The implementation of IGM countermeasure policy through Decree of Regent Number 13 of 2013 on the Formation of IGM Control Team has not run effectively among stakeholders in terms of coordination, as seen in the still-expanding area of environmentally damaging mining sites in Kuantan Singingi Regency. Legal certainty of Law Number 3 of 2020 should also be enforced in implementing the law. The regulation still does not exist hitherto. If it continues further, legal uncertainty may occur between local and central governments in the coordination and cooperation of minerals and coal.

\section{RQ.2: How is the implementation model of IGM countermeasure policy in Kuantan Singingi Regency?}

Previous studies have initiated and analyzed illegal mining problem from policy perspective, but they were unable to dive into the interactions and connections among the variables in implementing the IGM countermeasure policy in Indonesia. This study proceeds to explore the network within the policy implementation. Some of the previous studies are as follows: 
Table 4. Networks in the Implementation of Illegal Gold Mining Countermeasure Policy in Kuantan Singingi Regency

\begin{tabular}{l} 
Author and Title \\
\hline The Factors Influencing the \\
Implementation of IGM \\
Countermeasure Policy in Sepang \\
Sub-District, Gunung Mas \\
Regency, Central Kalimantan \\
(Haridison, 2016).
\end{tabular}

The Control of Illegal Gold Mining (IGM) in Indragiri Hulu Regency (Fahmi 2017).

The Coal Transport Policy Network in Jambi Province from the Perspective of Good Governance (Subhan, 2015).

Complexity and Public Policy: Network Model of Food Security Policy Implementation in Bone Regency (Alwi, A., \& Susanti, 2019).
This research employed the qualitative method approach. The qualitative method has several theoretical perspectives that can espouse a more in-depth analysis of the symptoms.

This study used a descriptive method with the qualitative approach by relying on secondary data to investigate the complexity of coal transport issues in Jambi Province.

This study used a qualitative approach. The data were primary data and secondary data gathered through interviews and observations.
Findings of the community was still in poverty, encouraging the community to resume the gold mining activities. (2) Provincial Spatial Plan of Central Kalimantan that the central government had not ratified affected the Spatial Plans of Gunung Mas Regency. This makes it difficult for the central government to determine the small-scale mining area for smallscale miners. (3) the coordination between institutions in the regions regarding the implementation of IGM countermeasure policy, especially among mining and other related departments, was still weak. (4) the resources to execute the regulations and procedures on the field were not yet officially available, constricting the control and supervision functions.

This research showed that in controlling IGM, the Regional Government made no policies in the forms of Regional Regulations to control IGM, resulting in a lack of control and supervision toward gold mining in Indragiri Hulu Regency.

The issue was due to a conflict of interests between the provincial government and the coal business owners. The drivers for coal transport became the tools of the coal business owners to show disobedience towards provincial policy. The key to solving this issue was to enforce the law and garner regency governments' support to espouse provincial policy.

Implementing a food security policy was ineffective since there was no comprehensive and integrated food program among the stakeholders. In this case, each governmental institution designed food security programs individually. Then, like a networkbased organization, the food security council had not carried out its function in coordinating 
What Makes a Key Player in Interorganizational Social Policy Networks? The Case of Uruguay (Biosca, O., \& Galaso, 2020).
Social Analysis Network (SNA) was implemented to study the network within the data sets. The article used node-level indicators that analyzed their relative position, focusing on centrality and attachment, to measure each organization's participation in the network, and synergizing stakeholders to create food programs that could prosper people.

Findings also showed that the relative interests of various organizations varied according to the form of interactions considered, highlighting the need to understand the complexities of policy networks better.

Kisby (2007) expounds that Marsh and Smith developed an advanced analysis model for policy networks. Marsh and Smith emphasize the importance of structural and deliberate explanation in policy-making within their analysis on the continuity and amendment of a policy. A Policy network plays a role in expounding how a policy is developed and implemented. The term "policy network" is understood as a general label that encompasses various forms of relations between state and private actors in policy-making (Kriesi, H., Adam, S., \& Jochum, 2007). The network organization involved in implementing public policy needs robust interaction, cooperation, and a high level of collaboration. The intensity of partnerships can also determine the involvement of an organization within the network. The nature of funding (public/private) and the authority of an organization's activities are investigated to determine social policy networks' influence and importance (Biosca, O., \& Galaso, 2020).

A policy network is formed in every stage of policy formulation. Howlett (1995) argues the formulation of a policy as a process consisting of a series of stages, i.e.: (1) alternative proposal stage, (2) alternative filtering stage, (3) alternative assessment stage, (4) alternative selection stage. Policy formulation or policy design is also a planning process (Quade, E. S., \& Carter, 1989). Policy networks will be accommodated in the organization. This organization is often called the policy subsystem. A policy subsystem in a policy formulation is formed when all parties, the leaders and the followers, among the various political groups, the public, and the private, participate in it, and interactions occur among the participants or stakeholders. The interactions among the stakeholders will form a relatively stable parameter (Wayne., 1997).

Policy networks are formed with some of the model's benefits to the private sector and government. Among these benefits, the network model allows each organization to focus more on the organization's core mission and utilize some expertise to carry out the task. Cooperation among organizations is integrated in solving problems (Zhao, R., Peng, H., \& Jiao, 2020). The network's capacity to implement policies and achieve the desired outcomes creates "additional value" from management expertise and practice. At the same time, increasing access to resources (financial, technology, human resources), other networks, and decision-makers (Wang, X. H., Chen, K., \& Berman, 2016). Further explanations regarding policy implementation are described as follows:

\section{Contextual assessment in understanding the environmental context, identifying stakeholders in policy implementation}

An implementation network is a policy network consisting of interactions between interdependent organizational stakeholders. A policy network is a multi-stakeholder, multisectoral system that operates on intertwined changes and maximizes influences and resources. In other words, building an implementation network is like building a political economy (Schroeder, 2001). The following discussion will be about stakeholder analysis and stakeholder management. The concept of stakeholder analysis suggests an effort to increase public participation and consideration by requiring institutions to increasingly implement a more 
legitimate public participation process beyond traditional understanding and formal hearings, as well as valid and essential normative/ethical components (Donaldson, Thomas, 1995).

According to Donaldson and Preston, all stakeholders' interests are intrinsic. Thus, it is acknowledged that moral values and obligations give a fundamental normative foundation for stakeholders. According to their mission and roles, stakeholders responsible for the implementation are also essential (Lajas, R., \& Macário, 2020). Stakeholder analysis, stakeholder management, and stakeholder theory emerged from various literatures that significantly impacted business and social literatures. Stakeholder analysis and management methods are recognized as required tools in a project manager's toolbox. According to Boutilier, R. G., \& Zdziarski (2017), three types of data can be combined to produce the best strategy to obtain and maintain the acceptance and support from stakeholders for the benefit of the social licensing project: (a) quantitative measures of the level of social permits granted, (b) empirical reports of connection networks, (c) quantification of concerns and priorities. Building good relationships and interactions can develop relevant liaison processes among the stakeholders, including building trust and maintenance. It can also assist in the slow and sometimes complicated process of reaching an agreement on policy-making (Lutz-Ley, A. N., Scott, C. A., Wilder, M., Varady, R. G., Ocampo-Melgar, A., Lara-Valencia, F., Zuniga-Teran, A. A., Buechler, S., Díaz-Caravantes, R., Ribeiro Neto, A., Pineda-Pablos, N., \& Martín, F., 2021).

The implementation of countermeasures for IGM in 2013 was based on the Regent's Decree on the Establishment of an IGM Control Team. This team controls and supervises all gold mining activities in the Kuantan Singingi Regency area with an integrated position. This policy focused on tackling IGM whose targets were the perpetrators of IGM in Kuantan Singingi Regency. From a political aspect, the implementation of IGM countermeasure policy has been stated in several regulations. They include the Law Number 4 of 2009 on Mineral and Coal Mining, Regulation of the Government Number 22 of 2010 on Mining Area, Regulation of the Government Number 23 of 2010 on the Implementation of Mineral and Coal Mining Business Activity, Regulation of the Government Number 55 of 2010 on the Development and the Inspection of Administration Management of Mineral and Coal Mining Business, and Regulation of the Minister of Energy and Mineral Resources Number 33 of 2009 in Conjunction with Regulation of the Minister of Energy and Mineral Resources Number 14 of 2011 on Delegation of A Part of Government Affair in the Field of Energy and Mineral Resources to Governors by Deconcentration in 2010/2011. When Law Number 4 of 2009 was about to be implemented, a new government regulation retracted the authority in mining management from regent/city with Law Number 23 of 2014. Consequently, the effort to change mining management's structuring and adjustment was initially based on Law Number 11 of 1967 with centralized nature into decentralized nature according to Law Number 22 of 2019 in Conjunction with Law Number 32 of 2004 on Regional Government of no avail.

After Law Number 4 of 2009 was replaced by Law Number 3 of 2020 on Mineral and Coal and Law Number 23 of 2014 on Regional Government, it was expected that each had their domain. The central government implements the laws on minerals and coal by performing its deconcentration function, delegating a part of the authority to the governors as the extensions of the central government in the regions. Meanwhile, Law Number 23 of 2014 retracted the authority from regional governments. However, the law should be consistent with mineral and coal law regarding mining. Regional governments, as the regional regulators, have to be aware of the illegal activities done by their residents. As the policy maker and executor, the government of Kuantan Singingi Regency must take actions against IGM to control them and to save the environment. The activities of IGM are estimated to have been occurring since 2006. 
Kuantan Singingi Regency issued the Decree of Regent Number 13 of 2013 on the Formation of IGM Team. This team's task was to control and supervise all gold mining activities within the the integrated team's position The implementation is still hindered since small-scale mining areas are still not legalized and the administration to get a small-scale mining permit in Kuantan Singingi Regency is complicated.

There are many stakeholders in implementing the IGM countermeasure policy. Kuantan Singingi Regency has the political will in its attempts to eradicate IGM activities, or at least to reduce the IGM activities in its area by forming an integrated team consisting of almost all elements of government both vertically and horizontally, i.e., the central government and the regional government. The integrated team consists of law enforcement officers, security, prosecutors, military, and the elements in the regional government. The team also involves community leaders to eradicate illegal mining persuasively.

\section{Joint Visioning in Policy Implementation}

The collaborative visioning process in implementing IGM countermeasure policy in Kuantan Singingi Regency involved all relevant stakeholders, both from the government and the community. According to the data, the Kuantan Singingi Regency government performed three steps in implementing control towards gold mining. They included: (1) The establishment of a sub-network for formulating goals; (2) The establishment of a sub-network for implementing programs; and (3) The establishment of operational implementation network.

This is by the opinion of (Schroeder, 2001) that the process of joint visioning has to establish sub-networks to facilitate the implementation activities. The three sub-networks were found, but not well coordinated. The first thing the local government did to respond to this predicament was to involve the target groups to discuss the programs together.

According to Schrooder (2001), to know the mission, vision, strategy, organizational structure, functional task, and the task of the new virtual organization, the functional subnetwork concept must be integrated at the service and implementation level. For these management activities to occur, various issues and programs must be agreed upon and developed at the executive decision level. The first step, stakeholders gather to discuss the possibility of implementing the new system, and the ideas from the stakeholders will begin to narrow down. Understanding how the new system will form and who will be responsible, starting from the internal structure. This unified view facilitates the development of initial commitment toward resources (the economy is starting to take shape).

The second step in the program-level sub-network is creating an operation plan and program that defines the boundaries on the integration at the service level on a case-by-case basis. The decision to devise the program results from the executive strategic choices, e.g., top staff (middle managers: program chair, planning director, budget deputy, and institution program director) formulates key details and domains of related institutions on how each integrated policy element is executed. The manager has knowledge of the program and adequate authority from the top that help him make organizational commitments regarding the aspects he is responsible for, commonly referred to as program-level sub-networks. For network facilitators, the purposes of the program-level sub-networks are (1) identifying opportunities to contribute in building a new network, (2) identifying possible implementation barriers (both internal and external), (3) identifying possible solutions for these obstacles, and (4) reporting back to the goal-setting network regarding the policy-level decision that may be required to facilitate further development of the program-level network.

Lastly, there is a development called operational implementation sub-network at the service contact level. At this level, operational relations for operations need to be established. The most common forms of relations are information distribution, agreements between institutions, access to all resources, and performance monitoring. The interaction process 
among the stakeholders within the network organization is very dependent on the elements of coordination. One of the interaction processes within the network organization is resource exchange in the network based on the depth of coordination among the interacting stakeholders within the network organization. The network organization is defined by the direct and indirect coordination between each stakeholder involved in the network organization. Network organizations can be arranged through routine coordination among the stakeholders involved in the network organizations (Mandell \& Steelman,2003). Gage, R. W., Mandell, M., \& Krane (1990), Rukmana S (2020) explains that the network organization is defined by the coordination that exists directly and indirectly between each stakeholder involved in the network organization. Network organizations can be arranged through routine coordination among the stakeholders involved in the network organizations.

The coordination within the network organization is an urgent element since the frequency in coordinating within a network organization cannot be substituted by rules, norms, and procedures that regulate the stakeholders in the network interaction process (Koliba, C., Meek, W.J, 2010). Fundamentally, the coordination within a network organization is depicted through a series of joint actions, i.e., coordinated mutual adjustment (Mintzberg, 1989), meaning coordination as an element in the system serving as the basis of collective efforts.

Coordination in a public policy network is a factor that determines the goal of network organization. Both individual and group stakeholders in the policy network must interact and coordinate to solve the public policy issues. Social network theory describes the interaction process as a structure that includes contact, trust, exchange of information, and exchange of resources that determine the sustainability and effectiveness of an organizational network. Coordination is an urgent dimension in a network organization. Coordination in the public policy network has not become the focus in policy network theory; hence the discussion of it in this research is a novelty of the idea and a fresh perspective for this research to investigate.

Referring to Gedeona Henrikus (theoretical review of networking management in the study of public policy), within the networking management approach, there is also a strategy that leads to managing interactions among stakeholders (Kickert, 1997). It can also be called a strategy that indirectly manages common perceptions. If this strategy is explored in-depth, there will be a resemblance of coordination activity among the stakeholders involved in the policy network.

The coordination has a broader meaning than the coordination concept proposed by several experts such as Levingstone (1949), L.D. White (1957), Mooney (1970), Herbert Hicks (1967), etc. The coordination they describe tends to point to the narrow definition of coordination, i.e., internal coordination, which is one of the principles of organization (Campbell, 1954). Meanwhile, coordination in this networking management relates to the interaction settings among the different stakeholders within its policy network to solve an issue or barrier to achieve specific shared goals.

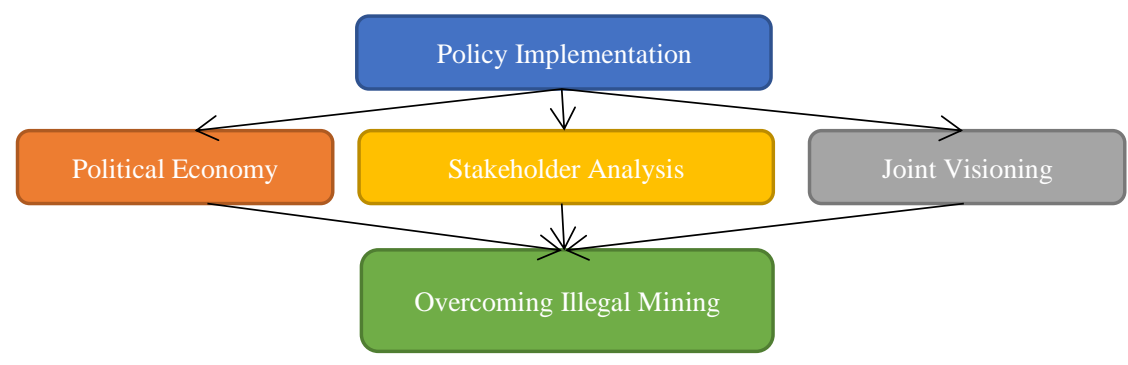

Figure 3. Policy Recommendations Model for Countering IGM 


\section{E. CONCLUSION}

This research reports 22 articles reviewed by the research topic regarding the implementation of IGM countermeasure policy. From the research findings, it can be concluded that the network in the implementation of IGM countermeasure policy in Kuantan Singingi Regency still had no cooperation framework between government and stakeholders in regard to IGM countermeasures. The policy only suggested the formation of an integrated team to control IGM. On the contextual assessment part in identifying stakeholders, it was found that the stakeholders involved both from the government and the community were less proactive in finding the synergy in controlling IGM. This unprevented illegal mining became the catalyst to broader environmental damage. The shared vision approach is one of the models offered to determine the success of this policy.

The numerous stakeholders involved in the network organization create complexity within a network, including the network for implementing IGM countermeasure policy in Kuantan Singingi Regency. The model network is imperative in the implementation of a network policy. The need to coordinate the cooperation among the stakeholders is essential in determining the success of the public policy implementation network. A policy implementation network will not run well without collaboration among the stakeholders.

\section{REFERENCES}

Abdullah, S. (2016). Kebijakan Penegakan Hukum Pidana Bagi Pelaku Dalam Menanggulangi Tindak Pidana Pertambangan Tanpa Ijin (Peti) Di Wilayah Hukum Polres Semarang. Unissula.

Alwi, A., \& Susanti, G. (2019). Complexity and Public Policy: Network Model of Food Security Policy Implementation in Bone Regency. Iapa Proceedings Conference, 522533.

Arlianti, P. (2017). Peran Pemerintah Daerah Dalam Penertiban Penambangan Emas Tanpa Izin Di Kecamatan Pangean Kabupaten Kuantan Singingi. Universitas Islam Negeri Sultan Syarif Kasim Riau.

Biosca, O., \& Galaso, P. (2020). What Makes a Key Player in Interorganizational Social Policy Networks? The Case of Uruguay. International Journal of Public Administration, 43(13), 1156-1168. https://doi.org/https://doi.org/10.1080/01900692.2019.1666407

Boutilier, R. G., \& Zdziarski, M. (2017). Managing stakeholder networks for a social license to build. Construction Management and Economics. 35(8-9), 498-513. https://doi.org/https://doi.org/10.1080/01446193.2017.1289229

Buli, W. (2018). Strategi Pengendalian Kerusakan Lingkungan Melalui Pembenahan Kelembagaan Pertambangan Batubara Tanpa Izin Studi Kasus Di Kabupaten Muara Enim Provinsi Sumatera Selatan. Universitas Lampung.

Campbell, R. N. (1954). Principles of Management.By George R. Terry (Book Review). Industrial and Labor Relations Review, 7(2), 319.

Carlsson, L. (2000). Policy Network as Collective Action. Policy Studies Journal, 28(3), 502520.

Darmono, Djoko, D. (2009). Mineral dan Energi Kekayaan Bangsa, Sejarah Pertambangan dan Enegi di Indonesia. Departemen Energi dan Sumber Daya Mineral.

Donaldson, Thomas, and L. E. P. (1995). The Stakeholder Theory of the Corporation: Concepts, Evidence, and Implications. Academy of Management Review, 20(1), 65-91.

Fahmi, A. (2017). Penertiban Penambangan Emas Tanpa Izin (Peti). Jurnal Demokrasi Dan Otonomi Daerah, 15(2), 139-144.

Ferry, M. (2013). Implementing Regional Policy in Poland: A New Era? Europe - Asia Studies, 65(8), 1578-1598. https://doi.org/https://doi.org/10.1080/09668136.2013.833016

Gage, R. W., Mandell, M., \& Krane, D. (1990). Strategies for managing intergovernmental 
policies and networks. Praeger.

Haridison, A. (2016). Faktor-Faktor Yang Memengaruhi Implementasi Kebijakan Penanggulangan Pertambangan Emas Tanpa Ijin Di Kecamatan Sepang Kabupaten Gunung Mas Kalimantan Tengah. Jurnal Universitas Paramadina, 10(2), 772-783.

Herbert, G, H. (1967). The Management of Organization. McGraw-Hill.

Howlett, M. and M. R. (1995). Studying Public Policy : Policy Cycles and Policy Subsystems. Oxford University Press, Oxford.Hydroelectric Relicensing." Energy Law Journal, implications for strategic management. Journal of Public Administration Research and Theory, 3(2), 209-231.

Kickert, W. E. H. K. dan J. K. (1997). Managing Complex Networks: Strategies for the Public Sector. Sage.

Kisby, B. (2007). Analyzing policy networks. Policy Studies, 28(1), 71-90. https://doi.org/https://doi.org/10.1080/01442870601121502

Koliba, C., Meek, W.J, Z. A. (2010). Public Administrati \& Public Policy. Governance Network in Public Administration \& Publici Policy., 1(58).

Kriesi, H., Adam, S., \& Jochum, M. (2007). Comparative analysis of policy networks in Western Europe. Journal of European Public Policy, 13(3), 341-361. https://doi.org/https://doi.org/10.1080/13501760500528803

Lajas, R., \& Macário, R. (2020). Public policy framework supporting "mobility-as-a-service" implementation. Research in Transportation Economics, 83(November 2019), 100905. https://doi.org/https://doi.org/10.1016/j.retrec.2020.100905

Livingston, R. T. (1949). The engineering of organization and management. McGraw-Hill.

Lutz-Ley, A. N., Scott, C. A., Wilder, M., Varady, R. G., Ocampo-Melgar, A., Lara-Valencia, F., Zuniga-Teran, A. A., Buechler, S., Díaz-Caravantes, R., Ribeiro Neto, A., PinedaPablos, N., \& Martín, F. (2021). Dialogic science-policy networks for water security governance in the arid Americas. Environmental Development, 38 , (August). https://doi.org/10.1016/j.envdev.2020.100568

Mandell, M., \& Steelman, T. (2003). Understanding what can be accomplished through interorganizational innovations The importance of typologies, context and management strategies. Public Management Review. 5(2), 197-224.

Marsh, D., \& Rhodes, R. A. W. (1992). Policy networks in British government. Clarendon Press.

Mintzberg, H. (1989). Mintzberg on management: Inside our strange world of organizations. Simon and Schuster.

Mooney, J. (1974). Principles of organization. Harpet and Brother.

Muhammad, M. (2019). Peran Pemerintah Dalam Upaya Penanggulangan Tambang Emas Ilegal Di Desa Lamunga Kecamatan Taliwang Kabupaten Sumbawa Barat. Doctoral Dissertation, Universitas Muhammadiyah Mataram.

Owusu, E. E., \& Dwomoh, G. (2012). The Impact Of Illegal Mining On The Ghanaian Youth: Evidence From Kwaebibirem District In Ghana. Research On Humanities And Social Sciences, 2(6), 86-93.

Quade, E. S., \& Carter, G. M. (1989). Analysis for public decisions. Cambridge: MIT Press.

Rahman, M. H., Naz, R., \& Nand, A. (2013). Public Sector Reforms in Fiji: Examining Policy Implementation Setting and Administrative Culture. International Journal of Public Administration, 36(13), 982-995. https://doi.org/10.1080/01900692.2013.773031

Rukmana S, N. S. (2020). Analisis Governance Network Dalam Jaringan Implementasi Kebijakan Ketahanan Pangan Di Kabupaten Bone (Doctoral dissertation, Universitas Hasanuddin).

Sabatier, P. A., \& Jenkins-Smith, H. C. (1993). Policy change over a decade or more. The nation's health. 
Santoso, B. (2018). Penegakan Hukum Terhadap Penambang Emas Tanpa Izin Berdasarkan Perda No. 3 Tahun 2012 Di Kabupaten Dharmasraya, Provinsi Sumatra Barat.

Schroeder, A. D. (2001). Building Implementation Networks: Building Multi-Organizational, Multi-Sector Structures for Policy Implementation. Dissertation. Public Administration and Public Affairs, Virginia Polytechnic Institute and State University.

Subhan. (2015). Jejaring Kebijakan Pengangkutan Batubara Di Provinsi Jambi Ditinjau Dari Perspektif Good Governance. CosmoGov: Jurnal Ilmu Pemerintahan, 1(1), 86-104.

Sujatmiko, B. (2012). Penambangan Emas Tanpa Izin Di Daerah Aliran Sungai (Das) Arut Kecamatan Arut Utara Ditinjau Dari Undang-Undang Nomor 4 Tahun 2009. Jurnal Ilmu Sosial, 4(1), 60-75.

Sunardi, E. \& A. S. (2017). Urgensi Lintasan Baru dalam pengelolaan sumber daya Mineral, Memuliakan Nilai masa depan. Unpad Press.

Suwitri, S. (2008). Jejaring Kebijakan Dalam Perumusan Kebijakan Publik Suatu Kajian Tentang Perumusan Kebijakan Penanggulangan Banjir dan Rob Pemerintah Kota Semarang. Jurnal Delegasi, Jurnal Ilmu Administrasi STIA Banjarmasin, 6(3), 1-32.

Thomas, J., \& Harden, A. (2008). Methods for the thematic synthesis of qualitative research in systematic reviews. BMC Medical Research Methodology, 8, 1-10. https://doi.org/https://doi.org/10.1186/1471-2288-8-45

Tummers, L., Vermeeren, B., Steijn, B., \& Bekkers, V. (2012). Public Professionals and Policy implementation: Conceptualizing and measuring three types of role conflicts. Public Management Review, 14(8), 1041-1059. https://doi.org/10.1080/14719037.2012.662443

Veronesi, G., \& Keasey, K. (2015). Patient and Public Participation in the English NHS: An assessment of experimental implementation processes. Public Management Review, 17(4), 543-564. https://doi.org/https://doi.org/10.1080/14719037.2013.822526

Wahiyuddin, L. O. (2020). Difusi Kebijakan Izin Usaha Pertambangan Di Provinsi Sulawesi Tenggara Policy Diffusion Of Mining Business Licenses In Southeast Sulawesi Province.

Wang, X. H., Chen, K., \& Berman, E. M. (2016). Building Network Implementation Capacity: Evidence from China. International Public Management Journal, 19(2), 264-291. https://doi.org/https://doi.org/10.1080/10967494.2015.1115791

Wayne., P. \&. (1997). Public Policy: An introduction to the theory and practice of policy analysis. Cheltenham: Edward Edgar Publishing.

White, L. D. (1929). Public Administration, 1928. American Political Science Review. 23(2), 427-440.

Xiao, Y. \& W. (2019). Guidance on conducting a systematic literature review. Journal of Planning Education and Research, 39(1), 93-112.

Zhao, R., Peng, H., \& Jiao, W. (2020). Dynamics of long-term policy implementation of Ecotransformation of industrial parks in China. 280, 124364. Journal of Cleaner Production. https://doi.org/https://doi.org/10.1016/j.jclepro.2020.124364 